\title{
Effects of Static and Dynamic Stretching on Muscle Architecture
}

\section{Statik ve Dinamik Germe Egzersizinin Kas Yapısı Üzerine Etkisi}

\author{
Ufuk Şekir ${ }^{1}$, Güfat Arslan², Osman İlhan ${ }^{1}$, Bedrettin Akova ${ }^{1}$ \\ ${ }^{1}$ Sports Medicine Department, Faculty of Medicine, Uludă̆ University, Bursa, Turkey \\ ${ }^{2}$ Sports Medicine Department, Gazi Yaşargil Training and Research Hospital, Diyarbakır, Turkey
}

\section{U.Șekir \\ 0000-0003-2735-8697 \\ G. Arslan \\ 0000-0001-7956-9539 \\ 0 . İhan \\ 0000-0002-8268-6717 \\ B. Akova (iD \\ 0000-0003-1044-8805}

Geliş Tarihi/Date Received: 08.10.2018

Kabul Tarihi/Date Accepted: 13.12.2018

Yayın Tarihi/Published Online: 29.04.2019

\section{Yazışma Adresi /}

Corresponding Author:

Ufuk Şekir

Bursa Uludağ Üniversitesi Tıp Fakültesi, Spor Hekimliği

Anabilim Dalı, Bursa, Turkey

E-mail: ufuksek@hotmail.com

(C)2019 Türkiye Spor Hekimleri Derneği. Tüm hakları saklıdır.

\section{ABSTRACT}

Objective: The aim of this study is to investigate the acute and chronic effects of static and dynamic stretching on muscle architecture of the peronealis longus and tibialis anterior muscles.

Materials and Methods: All 34 participants who volunteered for this study were randomly divided into static $(n=12)$, dynamic $(n=11)$ and control $(n=11)$ groups. The subjects in the stretching group performed stretching exercises for the ankle evertor and dorsiflexor muscles 5 days a week for 6 weeks. Morphological structures of peroneal and tibial muscles were evaluated at the beginning (2 times for acute effect) and the end of this period. Muscle architecture (pennation angle, fascicle length and muscle thickness) was evaluated by ultrasonographic measurements.

Results: Either in terms of acute or chronic effects, no significant differences were found following static and dynamic stretching exercises for peroneal and tibial muscle morphology parameters ( $p>0.05$ ).

Conclusion: It is possible to state that static and dynamic stretching exercises with a total duration of 240 seconds have no positive or negative effects on muscle architecture of the peroneus longus and tibialis anterior muscles in means of acute and long-term applications.

Keywords: Static stretching, dynamic stretching, ultrasound, fascicle length, pennation angle

\section{ÖZ}

Amaç: Bu çalışmanın amacı statik ve dinamik germe egzersizlerinin peroneus longus ve tibialis anterior kaslarının yapısı üzerine akut ve kronik etkilerini araştırmaktır.

Gereç ve Yöntemler: Çalışmaya katılan 34 katılımcının hepsi rastgele olarak statik $(n=12)$, dinamik $(n=11)$ ve kontrol $(n=11)$ gruplarına ayrılmıştır. Germe egzersizi grubundaki katılımcılar 6 hafta süre ile haftada 5 gün ayak bileği evertör ve dorsifleksör kaslarına germe egzersizleri uygulamışlardır. Peroneal ve tibial kasların morfolojik yapısı bu sürecin başında (akut etki için 2 kez) ve sonunda değerlendirilmiştir. Kas yapısı (pennasyon açısı, fasikül uzunluğu ve kas kalınlığı) ultrasonografik ölçüm yöntemleri ile değerlendirilmiştir.

Bulgular: Statik ve dinamik germe egzersizleri hem akut hem de kronik etki anlamında peroneal ve tibial kasların ultrason ile değerlendirilen morfolojik parametreleri üzerine anlamlı bir değişime neden olmamıştır $(p>0.05)$. 
Sonuç: Toplam süresi 240 saniye olan statik ve dinamik germe egzersizlerinin peroneus longus ve tibialis anterior kaslarının yapısı üzerine akut ve kronik etki anlamında olumlu veya olumsuz bir değişiklik oluşturmadığı söylenebilir. Anahtar Kelimler: Statik germe, dinamik germe, ultrason, fasikül uzunluğu, pennasyon açısı

Available at: http://journalofsportsmedicine.org and http://dx.doi.org/10.5152/tjsm.2019.128

Cite this article as: Sekir U, Aslan G, IIhan $\mathrm{O}$ et al. Effects of static and synamic stretching on muscle architecture. Turk $J$ $J$ Sports Med. 2019;54(3):158-68.

\section{INTRODUCTION}

Athletes and coaches, often depending on their personal choice, use different type of stretching exercises while preparing for training and competition (1,2). The commonly used techniques are ballistic, neuromuscular facilitation (PNF), static and dynamic stretching exercises $(3,4)$. Static and dynamic stretching exercises are the most preferred methods in the sports community (3).

Theoretically, stretching exercises performed either statically or dynamically have different attributes on muscle tissues in terms of applied force. Consequently, contractile and noncontractile structures of the muscle tissue may give different responses to these stresses over time. It has been shown that muscle fascicle length increases and pennation angle decreases following chronic passive stretching in the ankle plantarflexor muscles (5). Similar results were obtained in a histologic-based study executed in mice (6). When static stretching exercises (for 60 seconds and 10 repetitions) performed 3 days a week for 8 weeks in the triceps surae muscles of mice, there was a permanent reduction in pennation angle $(-25 \%)$, and a permanent increase in fascicle $(-8.5 \%)$ and sarcomere (-5\%) length. However, contradictory results have been seen in human studies with different stretching exercises. No effect was found with shorter stretching duration $(90-120 \mathrm{sec})(7,8)$, whereas longer stretch durations (450 sec) (9) generated changes in muscle fascicle structure (increase in fascicle length and decrease in pennation angle).

Currently, there are conflicts among studies evaluating the effects of pre-activity stretching (acute effects) $(5,10,11)$ or regular stretching after or outside periods of exercise as a long- term intervention (chronic) (7-9,12-16) on muscle structure. In general, the effects of static $(5,7-10,12,14)$, ballistic $(12,15)$ and PNF $(13,16)$ stretching have been investigated. No effect has been found with regular and long-term static stretching where total stretch duration was 90120 seconds $(7,8,12,14)$. However, Freitas and Mil-homens (9) stated that more intense and longer static stretching exercises (450 seconds) could increase the fascicle length and decrease the pennation angle. In studies investigating Achilles tendon stiffness, ballistic stretching decreased stiffness (12), whereas PNF stretching (13) was not effective. In contrast, long-term ballistic stretching did not affect the fascicle length, pennation angle, and muscle and tendon stiffness in the gastrocnemius muscle (15), while PNF stretching was effective on pennation angle and tendon stiffness in the same muscle group (16). The only study we found in the literature investigating the effects of dynamic stretching exercises on muscle morphology demonstrated that dynamic stretching performed just before exercise activities was not effective on fascicle length and pennation angle of the gastrocnemius muscle (11).

The architecture of a muscle (muscle thickness, fiber length and pennation angle) is an established predictor of its force generation (17). As tension increases in the muscle during a force generation, the pennation angle also increases (18). In other words, muscles including muscle fibers with higher pennation angle produce greater strength than the strength produced by muscles with lower pennation angle (19). It has been reported in narrative $(20)$, systematic $(21,22)$, and meta- 
analytical (23) review articles that static stretching represents decrements in torque production and dynamic stretching represents increments in torque production. Therefore, it would be useful to evaluate the effects of stretching exercises on muscle architecture also. It is obvious that the number of studies about the acute and chronic effects of static and dynamic stretching exercises on muscle morphology performed immediately before activity as an acute intervention and performed outside activity is insufficient in the literature.

Therefore, the aim of this study is to evaluate the acute and chronic effects of static and dynamic stretching exercises on the morphologic features of peroneal and tibialis anterior muscles.

\section{MATERIALS AND METHODS}

\section{Subjects}

Thirty-four healthy recreational male athletes participated in this study and were randomly assigned to either the static stretching $(n=12$, mean age $23.1 \pm 3.1$ year; mean height $175.1 \pm$ $6.9 \mathrm{~cm}$; mean body mass $68.1 \pm 7.1 \mathrm{~kg}$ ), dynamic stretching $(n=11$, mean age $22.6 \pm 3.9$ year; mean height $178.6 \pm 8.8 \mathrm{~cm}$; mean body mass $76.1 \pm 11.2 \mathrm{~kg})$ or the control group $(\mathrm{n}=11$, mean age $22.2 \pm 2.9$ year; mean height $179.0 \pm$ $5.7 \mathrm{~cm}$; mean body mass $73.6 \pm 12.5 \mathrm{~kg}$ ) using sealed, opaque envelopes. The allocation sequence and preparation of the concealed envelopes were completed by one study researcher (GA). The flow of the study and participant assignment procedures through the study have been described in Figure 1.

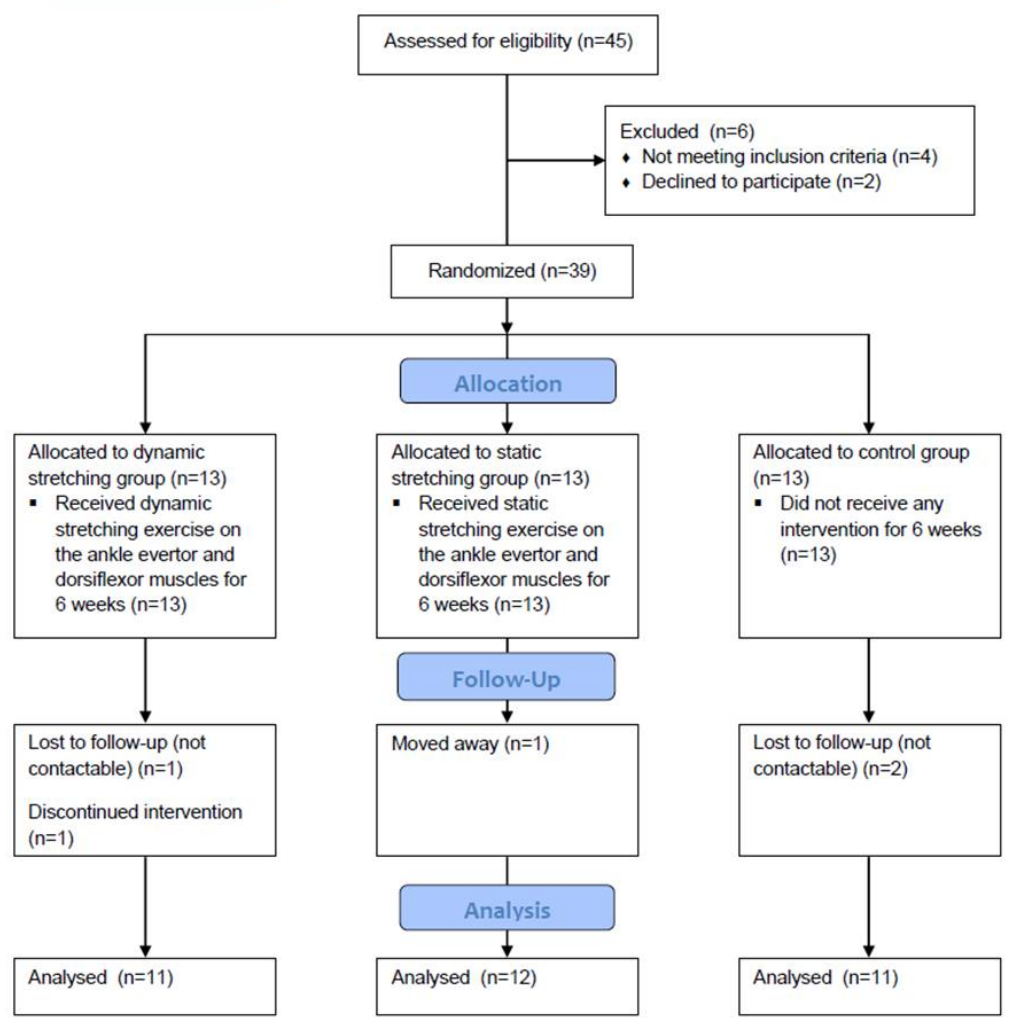

Figure 1. Flow diagram of participants 
The anthropometric data (age, height and body mass) showed no significant differences between groups according to the independent sample $t$-test $(\mathrm{p}>0.05)$. All 34 subjects enrolled in this study were regularly participating in recreational sports, such as running, soccer, or basketball one to two times a week for durations of 30-60 minutes. Participants were excluded from the study if they had or experienced an ankle sprain; low-back or lower extremity dysfunction; any ankle surgery or fracture or any occurrence of "giving way"; complained of pain, swelling, or functional limitations in the ankles; or took part in any therapeutic exercise for the ankles within the preceding 12 months. All of the participants had no mechanical ankle instability prior to participating in the study according to anterior drawer and talar tilt tests performed by the same clinician. All measurements were performed in the dominant leg. To be consistent with previous research studies, the leg that the participant uses to naturally kick a ball was defined as the dominant leg (24). There were 11 right- and 1 left-dominant subjects in the static stretching group, 9 right- and 2 left-dominant subjects in the dynamic stretching group and 10 right- and 1 left-dominant subjects in the control group.

The subjects read and signed the informed consent form about the test procedures, and any possible risks and discomfort that might ensue that were approved by the Uludağ University Institutional Ethical Board for Protection of Human Subjects (Approval number: 20157/13).

\section{Experimental Procedure}

Before initiating the experiments, the subjects were invited to the laboratory to receive information about the measurement procedure. Furthermore, stretching exercises (static or dynamic) that were planned to be performed on the ankle evertor and dorsiflexor muscles were demonstrated.

Muscle architecture evaluations of the peroneus longus and tibialis anterior muscles with ultrasound were performed on the same day. Subjects who were included in the stretching exercise groups (static or dynamic) performed the stretching exercises on the ankle evertor and dorsiflexor muscles 5 days a week for 6 weeks. To determine the acute effects of stretching, the measurements were repeated immediately within one to two minutes after completing the first stretching session. To see the chronic effects six week later, the measurements were performed the day after the participants completed the last stretching session. Blinding to treatment allocation of subjects was not possible due to the nature of the intervention groups. However, the principal investigator (US) was blinded to stretching exercise allocation and was responsible for baseline and follow-up assessments.

\section{Stretching Exercises}

Unassisted stretching exercises were designed for the ankle evertor (ankle in neutral and maximal plantarflexed positions) and dorsiflexor muscles in the dominant leg. The participants did not execute an active warm-up prior to the stretching protocol to avoid the possible effects of warm-up. The subjects implemented the stretching exercises 5 days a week for 6 weeks in the laboratory under supervision.

\section{Static Stretching}

Stretching exercises were carried out by the subjects themselves without external support to the point where they felt mild discomfort and tension but not pain, as acknowledged by the subjects. This position was maintained for 30 seconds. The stretching exercises were performed for 4 sets, each with a 30-second duration. The ankle was positioned to the resting position and held for 15 seconds between the sets and when the muscles to be stretched were changed.

Ankle Evertor Muscles (Peroneus longus and brevis)

These muscles were stretched with two different methods. The participant moved his 
ankle slowly inward (inversion) when the foot was on the ground in the first method. In the second method, the subject brought their ankle forward and inward with the help of their hands (plantarflexion and inversion). The stretching duration for the peroneal muscles with both stretching methods was 240 seconds in total.

\section{Ankle Dorsiflexor Muscles (Tibialis anterior)}

The subject, while seating on a chair, bent his knee joint and pulled the ankle back towards his thigh (plantarflexion). This position was held for 30 seconds. The total duration of the static stretching for this muscle group was 120 seconds.

\section{Dynamic Stretching}

Dynamic stretching has been performed by the contraction of the antagonist muscles of the target muscle group to be stretched in a rhythmic manner. For example, rhythmic active contractions of the ankle invertor muscles were performed to obtain dynamic stretching of the peroneal muscles. The stretching exercises were performed for 4 sets, each with a 30 -second duration. The ankle was positioned to the resting position and held for 15 seconds between the sets and when the muscles to be stretched were changed.

\section{Ankle Evertor Muscles (Peroneus longus and brevis)}

Two different dynamic stretching methods were performed. In the first method, the subject actively swung the ankle inward to the end of the range of motion where he felt tension (inversion) and returned back to the starting position, so that the ankle kept in neutral position. It has been repeated for 30 times with a frequency of 1 motion per second. In the second method, the subject pushed his toes to forward as far as possible (plantarflexion) and actively swung the ankle inward to the point where the ankle reached to the end of range motion and where tension was felt (inversion) and brought it back to the starting position. It has been repeated for 30 times with a frequency of 1 motion per second. The total duration of stretching with both stretching methods was 240 seconds.
Ankle Dorsiflexor Muscles (Tibialis anterior)

The subject, by contracting the calf muscles (gastrosoleus), actively push the ankle forward (plantarflexion) to the end of range of motion and to the point until tension was felt in the tibialis anterior muscle and brought it back to the starting position. It has been repeated for 30 times with a frequency of 1 motion per second. The total duration of the dynamic stretching for this muscle group was 120 seconds.

\section{Ultrasound Measurements}

The architecture parameters of the peroneus longus and tibialis anterior muscles were evaluated by an ultrasound (US) system (SonoScape Co. Ltd., Model S2, China) with a linear array probe $(60 \mathrm{~mm}, 5-10 \mathrm{MHz})$. The same physician performed this procedure for every participant (US). Muscle thickness, fascicle length and pennation angle were measured. All subjects were in supine position with their knees extended and ankles were in neutral position. The measurements were performed while the muscles were fully relaxed. Images for the peroneus longus muscle were obtained distal to the caput fibula at the superior lateral side of the dominant leg where the muscle belly was palpable. Images for the tibialis anterior muscle, on the other hand, were obtained at the superior $2 / 3$ part of the lower leg and $1 \mathrm{~cm}$ lateral to the anterior border of the tibia. The probe was held with a light touch in order to prevent any muscle deformation. The probe was held in the sagittal longitudinal plane parallel to the direction of the muscle fibers during the evaluations of the three muscle architecture parameters. Muscle thickness was determined as the distance between the superficial and deeper aponeurosis (Figure 2). Pennation angle was calculated from the insertion of the muscle fascicle to the aponeurosis (Figure 2). Finally, fascicle length was determined as the length of the fascicular path between the upper and deeper aponeurosis (Figure 2). When the fascicles extended off the acquired image, the panoramic mode of the software was used. The mean value of two measurements for each muscle architecture variable was calculated and considered for statistical analysis. 


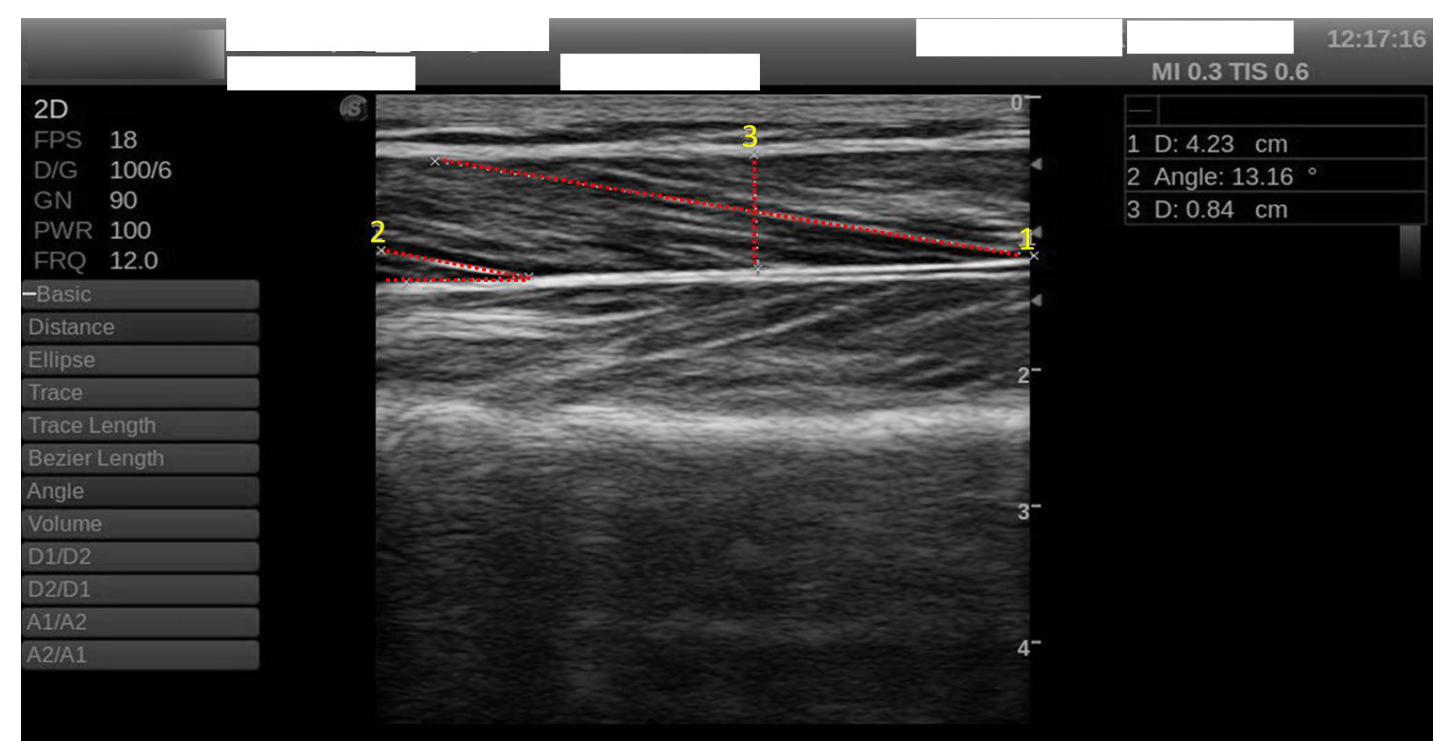

Figure 2. Ultrasonographic imaging of the peroneus longus muscle demonstrating the measurement of muscle thickness (3), fascicle length (1), and pennation angle (2) in an ankle-relaxed condition

\section{Reliability of Ultrasound Measurements}

Measurements were repeated one week later by the same researcher (US) in 25 of the subjects ( 9 from static, 9 from dynamic, and 7 from control group) to test the "intra-observer" reliability of US measurements (pennation angle, fascicle length, and muscle thickness). Meanwhile, the previous results were blinded in order to prevent researcher's bias. Reliability evaluation between the two measurements was made by calculating the intraclass correlation coefficient (ICC) using the "Two-Way Mixed" model. ICC values between 0.90-0.99, 0.80-0.89, 0.70-0.79, and below 0.69 indicate high, good, medium, and bad reliability, respectively (25). Table 1 shows the mean \pm SD values for muscle thickness, fascicle length, and pennation angle of the peroneus longus and tibialis anterior muscles and the ICC scores between the measurements. The ICC scores of the peroneus longus and tibialis anterior muscles were 0.70 and 0.92 for muscle thickness, 0.88 and 0.84 for fascicle length, and 0.86 and 0.72 for pennation angle, respectively. The stability of all measurements was assessed using the paired-sample $t$-test. There were no statistically significant differences between all tests $(p>0.05)$.

Table 1. Reliability values of ultrasound measurment data for peroneus longus and tibialis anterior muscle (mean \pm SD).

\begin{tabular}{lllll}
\hline & First Test & Second Test & ICC & P value \\
\hline PER-TH (mm) & $22.5 \pm 3.8$ & $21.7 \pm 3.8$ & 0.70 & 0.266 \\
TIB-TH (mm) & $31.2 \pm 2.4$ & $30.7 \pm 3.4$ & 0.92 & 0.097 \\
PER-FL (mm) & $40.2 \pm 10.3$ & $39.8 \pm 10.3$ & 0.88 & 0.820 \\
TIB-FL (mm) & $76.7 \pm 7.7$ & $78.5 \pm 8.1$ & 0.84 & 0.143 \\
PER-PA ( $\left.{ }^{\circ}\right)$ & $11.6 \pm 3.0$ & $11.6 \pm 2.9$ & 0.86 & 0.928 \\
TIB-PA $\left({ }^{\circ}\right)$ & $10.6 \pm 1.6$ & $11.0 \pm 1.8$ & 0.72 & 0.371 \\
\hline
\end{tabular}

PER= Peroneus longus, TIB= Tibialis anterior, $\mathbf{T H}=$ Muscle thickness, $\mathbf{F L}=$ Fascicle length, PA= Pennation angle, ICC $=$ Intraclass correlation coefficient. 


\section{Statistical Analysis}

Statistical analysis was performed using SPSS version 16.0 (SPSS, SPSS Inc., Chicago, Illinois, USA) software. Means and standard deviation were used to describe all variables. All tests were two-tailed, and the level of significance was set at $\mathrm{p}<0.05$. A priori power analysis was performed based on the reported values of previous studies (PASS 13 Power Analysis and Sample Size Software; NCSS, LLC, Kaysville, UT). According to the analysis, group sample sizes of $\mathrm{n} 1=\mathrm{n} 2=11$ would have $80 \%$ power to detect a mean difference of $10 \%$ and standard deviations of $15 \%$ between variables with a significance level (alpha) of 0.05. Repeated-measures 3 (stretch type) $\times 2$ (time) analysis of variance (ANOVA) model was used for comparisons of changes in US morphology parameters in stretching (static and dynamic) and the nonstretching control condition. This model was performed for analyzing both acute and chronic effects. In addition, an independent sample $t$ test was used to determine whether there was a probability of a significant difference between the three groups' pre-test mean scores and anthropometric data.

\section{RESULTS}

Table 2 presents the morphologic features of the peroneus longus and tibialis anterior muscles before and immediately after the first stretching session (acute effect) and at the end of 6 weeks of stretching exercises (chronic effect) in the three groups. The baseline values in muscle thickness, fascicle length, and pennation angle of the peroneus longus and tibialis anterior muscles were not different between the static, dynamic and control groups ( $p>0.05$, Table 2$)$. Furthermore, there was no significant "Group $\mathrm{x}$ Time" interaction for muscle thickness, fascicle length, and pennation angle in terms of acute and chronic effects between the groups according to the $3 \times 2$ ANOVA model ( $p>0.05$, Table 2).

\section{DISCUSSION}

The objective of our study was to investigate the effects of static and dynamic stretching exercises on the morphologic structure of the peroneus longus and tibialis anterior muscles in terms of both acute and chronic effects. We found no significant changes on muscle architecture following acute (evaluated immediately after first stretching) and chronic (evaluated following 6 weeks of regular stretching exercises) stretching.

The morphologic parameters of the peroneus longus and tibialis anterior muscles measured by ultrasonography in the present study are partially consistent with the literature. When all the three groups' results were taken together, the pre-exercise peroneus longus and tibialis anterior muscle thicknesses were $2.1-2.3 \mathrm{~cm}$ and 3.1-3.2 cm, fascicle lengths were $3.9-4.1 \mathrm{~cm}$ and 7.6-8.0 $\mathrm{cm}$, and pennation angles were 11$12^{\circ}$ and $10-11^{\circ}$, respectively. The number of studies evaluating these data in subjects with similar age groups and activity levels are limited in the literature. Sopher (26) has revealed the muscle volume, muscle length, fascicle length, pennation angle and cross-sectional area of the muscles around the ankle joint in 8 male cadavers with a mean age of 80 years. The fascicle length of the peroneus longus muscle $(3.7 \mathrm{~cm})$ and the pennation angle of the tibialis anterior muscle $\left(11^{\circ}\right)$ were consistent with our data, whereas the pennation angle of the peroneus longus muscle $\left(16^{\circ}\right)$ and fascicle length of the tibialis anterior muscle $(6.6 \mathrm{~cm})$ were slightly different from the data we obtained with ultrasonography. The age of cadavers might be the possible reason for these differences. Similar to our study, Reeves and Narici (27) investigated fascicle length and pennation angle of the tibialis anterior muscle in rested and maximal contracted position using an US system in young subjects with a mean age of 25 years. The fascicle length was found around $7.5 \mathrm{~cm}$ and pennation angle around 9.5 in neutral and rested ankle position. The fascicle length decreased to $5 \mathrm{~cm}$ and pennation angle 
Table 2. Muscle thickness, fascicle length, and pennation angle data for the peroneus longus and tibialis anterior muscles of the groups at the beginning and at the end of 6 weeks of stretching exercises (mean $\pm \mathrm{SD}$ ).

\begin{tabular}{|c|c|c|c|c|c|c|c|c|c|c|c|}
\hline \multirow[b]{3}{*}{ Peroneal } & \multicolumn{3}{|c|}{ Static } & \multicolumn{3}{|c|}{ Dynamic } & \multicolumn{3}{|c|}{ Control } & \multicolumn{2}{|c|}{$\begin{array}{c}P \text { value } \\
\text { (GroupxTime) }\end{array}$} \\
\hline & Before & After & 6Week & Before & After & 6Week & Before & After & 6Week & & \\
\hline & & & & & & & & & & Acute & Chronic \\
\hline $\begin{array}{l}\text { Thickness } \\
\text { (mm) }\end{array}$ & $22.2 \pm 3.4$ & $20.9 \pm 3.9$ & $19.6 \pm 2.4$ & $21.1 \pm 3.4$ & $21.0 \pm 3.1$ & $21.5 \pm 34$ & $22.9 \pm 4.4$ & $22.9 \pm 3.6$ & $23.4 \pm 3.6$ & 0.256 & 0.066 \\
\hline $\begin{array}{l}\text { Length } \\
\text { (mm) }\end{array}$ & $\begin{array}{l}40.4 \pm 14 . \\
2\end{array}$ & $41.1 \pm 14.3$ & $40.3 \pm 13.7$ & $41.4 \pm 5.9$ & $40.4 \pm 6.3$ & $39.5 \pm 6.1$ & $39.3 \pm 6.1$ & $39.2 \pm 5.1$ & $43.7 \pm 5.3$ & 0.782 & 0.172 \\
\hline Angle $\left({ }^{\circ}\right)$ & $11.3 \pm 3.9$ & $11.5 \pm 4.2$ & $11.0 \pm 3.7$ & $11.9 \pm 1.9$ & $12.0 \pm 1.9$ & $11.5 \pm 1.9$ & $11.9 \pm 1.9$ & $11.9 \pm 1.2$ & $11.6 \pm 1.7$ & 0.973 & 0.991 \\
\hline \multicolumn{12}{|l|}{ Tibial } \\
\hline $\begin{array}{l}\text { Thickness } \\
(\mathrm{mm})\end{array}$ & $30.5 \pm 1.8$ & $30.1 \pm 2.4$ & $29.6 \pm 2.9$ & $31.6 \pm 2.1$ & $31.9 \pm 2.1$ & $31.8 \pm 35$ & $31.7 \pm 2.7$ & $30.6 \pm 3.9$ & $30.6 \pm 3.0$ & 0.151 & 0.111 \\
\hline $\begin{array}{l}\text { Length } \\
(\mathrm{mm})\end{array}$ & $80.2 \pm 9.1$ & $80.5 \pm 8.4$ & $83.4 \pm 12.4$ & $75.8 \pm 7.9$ & $75.7 \pm 7.8$ & $78.0 \pm 7.4$ & $77.6 \pm 6.4$ & $76.5 \pm 7.6$ & $77.9 \pm 7.4$ & 0.839 & 0.610 \\
\hline Angle $\left({ }^{\circ}\right)$ & $9.7 \pm 1.7$ & $10.0 \pm 1.4$ & $9.8 \pm 1.9$ & $11.0 \pm 1.6$ & $10.8 \pm 1.7$ & $11.7 \pm 1.7$ & $11.4 \pm 1.5$ & $11.0 \pm 1.2$ & $11.5 \pm 1.1$ & 0.482 & 0.640 \\
\hline
\end{tabular}

PER= Peroneus longus, TIB= Tibialis anterior, 6 Week= following 6 weeks of stretching exercise program, Acute= interaction after the first stretching exercise, Chronic= interaction between the baseline and the end of 6 weeks of stretching program 
increased to $14^{\circ}$ in ankle neutral and maximal contracted position. The fascicle length (7.6-8 $\mathrm{cm})$ and pennation angle $\left(10-11^{\circ}\right)$ of the tibialis anterior muscle measured by ultrasonography in rested position were similar in the present study. In another study, Chleboun et al. (28) evaluated the fascicle length of the tibialis anterior muscle using real-time ultrasound imaging during walking in young subjects with a mean age of 23 years. While the fascicle length was the shortest (approximately 5.5-5.6 cm) at the beginning and end of walking phase, it reached the longest $(6.2 \mathrm{~cm})$ in the middle of this phase. Although it is difficult to compare these values directly with the data in the present study, tibialis anterior muscle length when it was in rest in a certain extent and contracted position during walking is partially consistent with our data.

\section{Stretching effects}

There are various investigations in the literature that examine changes in muscle morphology with ultrasound following stretching exercises (5-11,14,15,29-31). These were mostly carried out in the gastrocnemius, hamstring and quadriceps muscles.

\section{Acute Effects}

Abellaneda et al. (5) evaluated the changes in fascicle length and pennation angle of the gastrocnemius muscle when the ankle plantarflexor muscles were passively stretched from $10^{\circ}$ plantarflexion to $30^{\circ}$ dorsiflexion. Fascicle length showed an increase from 57.6 $\mathrm{mm}$ to $80.5 \mathrm{~mm}(+40.9 \%)$, and a decrease have been observed in pennate angle from $21.2^{\circ}$ to $14.5^{\circ}(-30.7 \%)$ in the medial head of the gastrocnemius muscle following passive stretching that was analogous to static stretching. The measurements were made in real time during stretching in this study. The changes in muscle architecture have not been evaluated after the stretching exercises were completed. Similar to the above studies, Morse et al. (10) have found that fascicle length increased from $65 \mathrm{~mm}$ to $75 \mathrm{~mm}$ and pennation angle decreased from $18.3^{\circ}$ to $15.4^{\circ}$ in the medial head of the gastrocnemius muscle while the ankle joint was passively dorsiflexed from neutral $\left(0^{\circ}\right)$ to $25^{\circ}$ of range of motion at a constant angular velocity of $1^{\circ} / \mathrm{sec}$. However, fascicle length $\left(0^{\circ}=61 \mathrm{~mm}, 25^{\circ}=71 \mathrm{~mm}\right)$ and pennation angle $\left(0^{\circ}=21.7^{\circ}, 25^{\circ}=15.7^{\circ}\right)$ did not show a statistical significant change following the maximal static stretching applied to the gastrocnemius muscle for a total duration of 300 seconds (5 sets and 60 seconds). Similarly, Konrad et al. (30) aimed also to expose the effects of static stretching to the gastrocnemius muscle for a total duration of 120 seconds (4 set and 30 seconds). Fascicle length and pennation angle of the medial part of the gastrocnemius muscle represented no change in neither the relaxed nor maximally stretched positions. Nakamura et al. (29) assessed the fascicle length of the gastrocnemius muscle before, immediately after and 10 minutes after static stretching (bringing the ankle to $30^{\circ}$ dorsiflexion) for a total duration of 300 seconds with 5 repetitions of 60 seconds. The authors expressed that there were no significant changes in fascicle lengths measured at the angles of $0^{\circ}, 5^{\circ}, 10^{\circ}, 15^{\circ}, 20^{\circ}, 25^{\circ}$ and $30^{\circ}$ of dorsiflexion immediately and 10 minutes after stretching. Sa et al. (31) applied static stretching to the quadriceps and hamstring muscles and found no significant changes in fascicle length and pennation angle of the vastus lateralis and biceps femoris muscles immediately after 30 seconds of static stretching exercise. In one of the few studies that investigated the effects of dynamic stretching on muscle architecture, Samukawa et al. (11) aimed to represent changes in pennation angle and fascicle length of the medial head of the gastrocnemius muscle following 5 sets and 30 seconds of dynamic stretching exercises. There were no significant changes in fascicle length and pennation angle measured immediately after each set of dynamic stretching exercises when compared to baseline values. The authors stated that they investigated the short-term effects of dynamic stretching and emphasized the need for further research to detect the long-term effects. Similar to the studies mentioned above, static and dynamic stretching exercises have found to have no significant acute effects on the fascicle length, 
pennation angle or muscle thickness of the peroneus longus and tibialis anterior muscles in the present study.

\section{Chronic Effects}

After getting the impression that static stretching exercises did not cause an acute change in muscle morphology, researchers concentrated on the effect of stretching exercises over a long period of time. The subjects in the study of Nakamura et al. (7) applied 2 sets of 60 -second static stretching exercises to the medial gastrocnemius muscle per day for 4 weeks. Static ankle dorsiflexion stretching did not cause a significant impact on the fascicle lengths evaluated at $0^{\circ}(\sim-0.3 \mathrm{~cm})$ and $30^{\circ}(\sim-0.1 \mathrm{~cm})$. Konrad and Tilp (14) applied similar static stretching exercises 5 days a week for 6 weeks consisting of 4 sets of 30 seconds. They found that static stretching exercise did not induce significant changes in the fascicle lengths or pennation angles of the gastrocnemius muscle in rested and maximally stretched conditions. The authors claimed that increase in ankle range of motion following static stretching was due to adaptation of the nociceptive nerve endings rather than changes in muscle and tendon tissue. The pennation angle, fascicle length and muscle thickness of the vastus lateralis and biceps femoris muscles also represented no significant variations after an 8-week static stretching exercise that was applied 3 times a week ( 3 set $x 30$ seconds) in the study of Lima et al. (8). The authors concluded that the stretching program was not effective because of the intensity and frequency. In fact, according to the results of the abovementioned studies, it has been seen that there is no effect on muscle morphology of regular and long-term static stretching exercises with a total stretching time of $90-120$ seconds and a total stretching sessions of 24-30. With a longer stretching duration (120-240 seconds) and a total stretching sessions of 30 (5 days per week for 6 weeks), we could not observe any effects of static stretching exercises on muscle morphology in the present study, as well. Several studies revealed that long-term stretching exercises with longer stretching durations might cause changes in muscle morphology $(6,9)$. Peixinho et al. (6) performed 60 seconds of static stretching with 10 repetitions in the triceps surae muscles of mice. These exercises were continued 3 days a week for 8 weeks. At the end, the pennation angle presented a permanent decrease of $25 \%$, and the fascicle and sarcomere length exhibited a permanent increase of $8.5 \%$ and $5 \%$, respectively. Freitas and Mil-homens (9) also found a significant increase in the fascicle length $(+12.3 \mathrm{~mm},+13.7 \%)$ of the biceps femoris muscle after static stretching exercises for 450 seconds at pain threshold, where the effects of a high-intensity static stretching exercise consisting of 3.1 times a week for 8 weeks was investigated. The pennation angle also decreased by $10.8 \%\left(-1.7^{\circ}\right)$, although it was not statistically significant. Freitas and Mil-homens (9) have suggested that stretch intensity and duration are important factors in muscle morphology adaptations. Considering these findings, we could state that the stretching period that we applied in the present study might have been insufficient to produce an significant effect on muscle morphology.

\section{CONCLUSION}

It was found that static and dynamic stretching exercises with a total duration of 240 seconds did not have a significant effect on muscle architecture in means of both acute and longterm applications. It would be useful to carry out further studies with static and dynamic stretching exercises with longer durations.

\section{Acknowledgements}

This research was supported by The Scientific and Technological Research Council of Turkey (TUBITAK); Project Number: 115S811.

\section{REFERENCES}

1. ACSM. General principles of exercise prescription. In: Franklin BA, Whaley MH, Howley ET, Balady GJ, editors. Guideline for exercise testing and prescription. $1^{\text {st }}$ ed. Baltimore: Williams and Wilkins; 2000. p. 137-64.

2. Holcomb WR. Stretching and warm-up. In: Baechle TR, Earle RW, editors. Essentials of strength training and conditioning. $2^{\text {nd }}$ ed. Champaign Ill: Human Kinetics; 2000. p. 321-42. 
3. Alter MJ. Sports Stretch. Champaign, IL: Human Kinetics, 1997.

4. Hedrick A. Dynamic flexibility training. Strength Cond J. 2000;22:33-8.

5. Abellaneda S, Guissard N, Duchateau J. The relative lengthening of the myotendinous structures in the medial gastrocnemius during passive stretching differs among individuals. J Appl Physiol (1985). 2009;106(1):169-77.

6. Peixinho CC, Martins NSF, de Oliveira LF, ve ark. Structural adaptations of rat lateral gastrocnemius muscle-tendon complex to a chronic stretching program and their quantification based on ultrasound biomicroscopy and optical microscopic images. Clinical Biomechanics. 2014;29:57-62.

7. Nakamura M, Ikezoe T, Takeno Y, ve ark. Effects of a 4week static stretch training program on passive stiffness of human gastrocnemius muscle-tendon unit in vivo. Eur J Appl Physiol. 2012;112:2749-55.

8. Lima KM, Carneiro SP, de S Alves D, ve ark. Assessment of muscle architecture of the biceps femoris and vastus lateralis by ultrasound after a chronic stretching program. Clin J Sport Med. 2015;25(1):55-60.

9. Freitas SR, Mil-Homens P. Effect of 8-week highintensity stretching training on biceps femoris architecture. J Strength Cond Res. 2015;29:1737-40.

10. Morse CI, Degens H, Seynnes OR, ve ark. The acute effect of stretching on the passive stiffness of the human gastrocnemius muscle tendon unit. $J$ Physiol. 2008;586(1):97-106.

11. Samukawa M, Hattori M, Sugama N, ve ark. The effects of dynamic stretching on plantar flexor muscle-tendon tissue properties. Man Ther. 2011;16(6):618-22.

12. Mahieu NN, McNair P, De Muynck M, ve ark. Effect of static and ballistic stretching on the muscle-tendon tissue properties. Med Sci Sports Exerc. 2007;39(3):494501.

13. Mahieu NN, Cools A, De Wilde B, ve ark. Effect of proprioceptive neuromuscular facilitation stretching on the plantar flexor muscle-tendon tissue properties. Scand J Med Sci Sports. 2009;19(4):553-60.

14. Konrad A, Tilp M. Increased range of motion after static stretching is not due to changes in muscle and tendon structures. Clin Biomech (Bristol, Avon). 2014;29(6):636-42.

15. Konrad A, Tilp M. Effects of ballistic stretching training on the properties of human muscle and tendon structures. J Appl Physiol (1985). 2014;117(1):29-35.

16. Konrad A, Gad M, Tilp M. Effect of PNF stretching training on the properties of human muscle and tendon structures. Scand J Med Sci Sports. 2015;25:346-55.
17. Lieber RL, Friden J. Functional and clinical significance of skeletal muscle architecture. Muscle Nerve. 2000;23:1647-66.

18. Kawakami Y. The effects of strength training on muscle architecture in humans. International Journal of Sport and Health Science. 2005;3:208-17.

19.Liem KF, Bemis WE, Walke, WF, Grande L. Function anatomy of the vertebrates: an evolutionary perspective. Cengage Learning, 2001.

20.Behm DG, Chaouachi A. A review of the acute effects of static and dynamic stretching on performance. Eur J Appl Physiol. 2011;111:2633-51.

21.Behm DG, Blazevich AJ, Kay AD, ce ark. Acute effects of muscle stretching on physical performance, range of motion, and injury incidence in healthy active individuals: a systemic review. Appl Physiol Nutr Metab. 2016;41:1-11.

22. Kay AD, Blazevich AJ. Effect of acute static stretch on maximal muscle performance: a systematic review. Med Sci Sports Exerc. 2012;44(1):154-64.

23. Simic L, Sarabon N, Markovic G. Does pre-exercise static stretching inhibit maximal muscular performance? A meta-analytical review. Scand J Med Sci Sports. 2013;23:131-48.

24. Knight AC, Weimar WH. Difference in response latency of the peroneus longus between the dominant and nondominant legs. J Sport Rehabil. 2011;20:321-32.

25.Currier DP. Elements of research in physical therapy. 3rd ed. Baltimore, MD: Williams and Wilkins; 1990.

26. Sopher RS, Amis AA, Davies DC, ve ark. The influence of muscle pennation angle and cross-sectional area on contact forces in the ankle joint. J Strain Analysis. 2017;52:12-23.

27. Reeves ND, Narici MV. Behaviour of human muscle fascicles during shortening and lengthening contractions in vivo. J Appl Physiol. 2003;95:1090-6.

28. Chleboun GS, Busic AB, Graham KK, ve ark. Fascicle length change of the human tibialis anterior and vastus lateralis during walking. JOSPT. 2007;37:372-9.

29. Nakamura M, Ikezoe T, Takeno Y, ve ark. Acute and prolonged effect of static stretching on the passive stiffness of the human gastrocnemius muscle tendon unit in vivo. J Orthop Res. 2011;29:1759-63.

30. Konrad A, Stafilidis S, Tilp M. Effects of acute static, ballistic, and PNF stretching exercise on the muscle and tendon tissue properties. Scand J Med Sci Sports. 2016, Jul 1. doi: 10.1111/sms.12725. [Epub ahead of print].

31.Sa MA, Matta TT, Carneiro SP, ve ark. Acute effects of different methods of stretching and specific warm-ups on muscle architecture and strength performance. $J$ Strength Cond Res. 2016;30:2324-9. 